\title{
MÚSICA RELIGIOSA INGLÊSA DO SÉCULO XVII.
}

Estas notas foram sugeridas por um disco, editado já há algum t€mpo, mas que só ùltimamente tivemos oportunidade de conhecer, reunindo algumas composições de três autores inglêses dos séculos XVI e XVII, a saber: Peter Philips (1560-1633), Orlando Gibbons (1583-1625) e Matthew Locke (1632-1677) (1). Sem entrar na apreciação do disco em si, nem na do conjunto que teve a seu cargo a execução dessas obras, queremos, contudo, ressaltar o interêsse dêsse programa de música religiosa inglêsa, sobretudo por tratar-se de compositores ignorados entre nós e de cujo conhecimento nem os próprios discófilos podiam gabar-se, pois, a não ser duas ou três pequenas páginas de Gibbons, nada mais havia, antes, merecido as honras da gravação. O disco em apreço nos deu a conhecer apenas uma pequena parcela do muito que escreveram. Parcela que permite, entretanto, avaliar o mérito de suas produçōes e principalmente o papel que representaram na evolução da música inglêsa.

O que tem chegado ao nosso conhecimento da música inglêsa do século XVII é deveras surpreendente. Bastariam os nomes de Blow e de Purcell para que considerássemos a Inglaterra um dos países mais importantes, sob o ponto de vista musical, do mundo de então. Todavia, cumpre não esquecer os compositores menores que atuaram como que preparando o terreno para a obra imensa de Purcell. Este trabalho precursor vem desde o século XVI, com Henrique VIII, curioso monarca que tinha também suas veleidadesinhas de compositor. Não foi à-toa que já nessa época Erasmo de Roterdão, o grande humanista da Renascença, escreveu que "os inglêses podiam considerar-se, entre todos os povos, o de melhor aparência, o mais musical e o de melhor mesa". (O grifo é nosso).

A grande contribuição dos inglêses dessa época para a música foi o madrigal. Embora originário da Itália, foi na Inglaterra que essa delicada forma musical atingiu o máximo de sua perfeição. Conhecem-se noventa e duas coleções de madrigais publicadas na Inglaterra no meio século que vai de 1588 a 1638. Uma delas, talvez a mais famosa — "The Triumphes of Oriana" -, foi editada (1). - Sacred Music of the 17th Century: Orlando Gibbons, Peter Philips, Matthew 
em 1601 por Thomas Morley, em honra da rainha Isabel (2). Um estrangeiro de nome Galliard, que residiu na Inglaterra, deixou as seguintes impressões sôbre a música daquele tempo: "Os madrigais estavam muito em moda no reinado da rainha Isabel e os inglêses da época deram provas de sua capacidade para essas composições, chegando a rivalizar com os melhores compositores italianos. Ninguém podia considerar-se possuído de uma boa educação liberal, se não conhecesse bastante música para cantar o seu papel à primeira vista e, nas reunióes de senhoras e cavalheiros, era comum colocarse livros de madrigais diante dos presentes, para que cada um cantasse a sua parte. . . Mas, depois do glorioso reinado da rainha Isabel, a música (pela qual a Inglaterra era famosa no mundo inteiro, assim como pelas outras artes) foi tão abandonada, não só devido à falta de estímulo dos poderosos, como devido à guerra civil que, afinal, essa arte se perdeu completamente" (3).

Realmente, os acontecimentos políticos que abalaram a Inglaterra na primeira metade do século XVII exerceram profunda influência sôbre a vida musical do país. Não só os políticos, mas também os religiosos. Assim, ao lado de reis que não tiveram o menor interêsse pelas artes (como os primeiros sucessores de Isabel, Jaime I e Carlos J), encontramos o puritanismo rígido, exagerado e intransigente que dominou a vida inglêsa dessa época, banindo a música da igreja, na sua preocupação de simplificar ao máximo o culto cristão (4). Este estado de coisas durou pelo menos até à restauração, de maneira que assistimos, na segunda metade do século XVII, a um novo florescimento da música, com as já mencionadas figuras de Blow e Purcell.

Convém não esquecer, entretanto, que mesmo durante êsse período de retraimento, que foi a primeira metade do século XVII, não cessaram as atividades musicais na Ilha. $O$ que se verifica, porém, é mínimo comparado com os tempos de Isabel. Conhecemse os nomes de diversos músicos que, por falta de serviço na sua especialidade, tiveram que procurar outros meios de vida (5). Sabe-se, ainda, que o próprio Cromwell apreciava a música e chegou a ter em seu palácio um organista para distraí-lo com motetes religiosos e para ensinar a arte divina às suas filhas. Mas, - como observa De Candé - os funcionários da república eram mais in-

(2). - Dessa interessante coleção de madrigais foi feita recentemente, sob a direção de David Randolph, uma gravação integral ( 32 peças) comemorativa da coroação de Elisabeth II, que é, também, grande entusiasta dessa forma musical. Sabe-se que a jovem rainha manteve por muito tempo (e talvez ainda mantenha), sob sua própria direção, no Palácio de Buckinghan, um dos mais finos conjuntos madrigalescos da Inglaterra.

(3). - Apưd W. J. Turner, A música inglêsa, p. 15. Trad. de Lyra Cavalcanti. Rio, José Olympio, s.d.

(4). - Ver sôbre o assunto, entre outros, Roland De Candé, Petite histoire de la musique anglaise, cap. IV e Eric Blom, Music in England, caps. III e IV.

(5). - Roland De Candé, op. cit., p. 71. 
transigentes do que o próprio Cromwell e o caso citado não passa de rara exceção.

Tôdas essas contingências políticas e religiosas tornam ainda mais interessante e mais valiosa a obra realizada pelos poucos compositores que, nessa época, mantiveram aceso o facho que iluminava a vida musical inglêsa. $E$ são três dentre êsses compositores que vêem apresentados no disco que sugeriu êstes comentários. Dêles, o mais conhecido e mesmo o de maior valor é Orlando Gibbons, que chegou a organista da Abadia de Westminster. Sua reputação firmou-se principalmente pelo que produziu no setor da música sacra. Não se deve desprezar, porém, o que escreveu em outros gêneros de música instrumental (fantasias, prelúdios, galiardas, pavanas) ou vocal (madrigais, motetes, "máscaras") (6). Grande parte de sua obra foi incluida numa coleção de música sacra (First Book of Selected Church Music) editada por Bernard em 1641. Nessa coleção figuram seis das sete peças de sua autoria, gravadas no disco a que nos referimos: This is the record of John (inspirada no testemunho de João Batista e utilizando as próprias palavras do cap. I, versos 19 a 23 do Evangelho de São João), Nunc Dimitis, $O$ Lord, increase my faith, The eyes of all wait upon Thee, o Lord, Almighty and everlasting God e $O$ God, the King of Glory. Completa o programa o Magnificat (texto inglês) para uma das duas séries de peças que Gibbons compôs para o ofício de Vésperas da liturgia anglicana.

Matthew Locke é considerado o mais importante precursor de Purcell como compositor de música de cena. Atribuem-se-lhe, entre outras coisas, algumas das primeiras composiçōes inspiradas em Shakespeare (Macbeth e The Tempest). Os três hinos de sua autoria que figuram no disco citado (Lord, let me know mine end, $O$ give thanks unto the Lord e Sing unto the Lord a new song) exemplificam bem o sentimento religioso do compositor, notadamente o primeiro dêles.

Quanto a Peter Philips, embora tão inglês quanto os outros, viveu grande parte de sua vida no continente e as influências que recebeu das escolas flamenga e italiana foram sensiveis. Sweelinck, sobretudo, parece ter exercido profunda marca no estilo religioso do compositor, enquanto que a veia italiana reflete-se nos seus madri. gais. Figura, assim, Philips como uma espécie de elemento de ligação entre a Inglaterra e o continente, nesse século musicalmente tão importante que foi o XVII. Ao contrário de Gibbons e de Locke, cujos hinos são todos com texto inglês, os de Philips foram escritos sôbre textos latinos, o que vem revelar, de maneira inequívoca, a in-

(6). - Uma relação completa das obras de Orlando Gibbons poderá ser encontrada no vol. II do Grove'z Dictionary of Music and Mussicians, 3a. edição, verbete Grbbons. 
fluência que sôbre sua obra exerceu a música religiosa continental, quase tôda, nessa época, prêsa ainda ao espírito litúrgico católicoromano. As peças de Philips que figuram nesse valioso programa de música inglêsa antiga, que é o disco da Allegro, intitulam-se Ascendit Deus, Hodie Sanctus Benedictus e Surgens Jesus.

A gravação dêsse disco veio trazer, pois, aos estudiosos da história da música um excelente material de trabalho, uma vez que, conforme observamos, encerra composições de autores até agora pràticamente desconhecidos, mas de grande importância para a evolução da música inglêsa. O trabalho imenso que realizaram, às vêzes em condições pouco ou nada favoráveis, permitiu que se mantivesse vivo o interêsse dos inglêses pela música, preparando o país para a grande época de Purcell, na segunda metade do século XVII.

ODILON NOGUEIRA DE MATOS 